\title{
The Implementation of Waqf to Actualize Economic Justice Based on Islamic Law
}

\author{
Helza Nova Lita* \\ DOI: https://doi.org/10.22304/pjih.v7n1.a1
}

Submitted: February 28, 2020 | Accepted: April 25, 2020

\begin{abstract}
Economic justice is one of the objectives of the implementation of Islamic economic system. Waqf is one of the instruments of Islamic economics. It is interesting to study the implementation of economic justice through waqf and how its regulation in Indonesia. This article employed normative juridical method. Based on the Article 22 of the Law Number 41 of 2004 on Waqf, the purpose of waqf is not solely for the purpose of ritual. It can also be used to realize economic prosperity. Based on these provisions, waqf can be managed for the economic empowerment of the people. This is related to the efforts of the improvement of the economic welfare of the people, especially for the weak economic class. According to Islamic teachings, distributive justice is economic justice based on the Holy Quran, Chapter al-Hasyr (59): 7. Waqf has the potential to create the economic balance of society. Because the principle of ownership, according to Islam, regulates that individuals or certain community members are not the only party who control the management of assets. The weak economic class also have the right. It is to avoid economic inequality. Thus, waqf is a solution to actualize economic justice in order to realize public welfare, which is one of Indonesia's national goals as stated in the Preamble of the 1945 Constitution of the Republic of Indonesia.
\end{abstract}

Keywords: implementation, islamic law, waqf

\section{Implementasi Wakaf dalam Mewujudkan Keadilan Ekonomi Menurut Hukum Islam}

\begin{abstract}
Abstrak
Keadilan ekonomi merupakan salah satu tujuan implementasi sistem ekonomi Islam yang tercermin dari mekanisme yang ditetapkan dalam hukum Islam. Wakaf merupakan salah satu instrumen ekonomi Islam. Hal ini menarik untuk dikaji lebih lanjut, bagaimana makna keadilan ekonomi dalam Islam itu sendiri yang diimplementasikan melalui wakaf, serta bagaimana pengaturannya di Indonesia. Metode yang digunakan dalam pembahasan artikel ini adalah yuridis normatif. Berdasarkan ketentuan Pasal 22 Undang-Undang Nomor 41 Tahun 2004 tentang Wakaf, tujuan wakaf tidak semata-mata untuk kepentingan ibadah ritual semata. Namun juga dapat digunakan untuk mewujudkan kesejahteraan bidang ekonomi. Berdasarkan ketentuan tersebut, Wakaf dapat dikelola untuk pemberdayaan
\end{abstract}

PADJADJARAN Journal of Law Volume 7 Number 1 Year 2020 [ISSN 2460-1543] [e-ISSN 2442-9325]

Lecturer of Economic Law Department Faculty of Law Universitas Padjadjaran, Jalan Dipati Ukur No. 35, Dr., S.H., M.H. (Universitas Padjadjaran), helza.nova@unpad.ac.id 
ekonomi umat. Hal ini sangat terkait dalam upaya meningkatkan kesejahteraan ekonomi masyarakat, khususnya untuk kelompok ekonomi masyarakat lemah. Keadilan disributif merupakan keadilan ekonomi menurut ajaran Islam berdasarkan Al-Qurán surat al-Hasyr [59]:7. Melalui wakaf dapat diwujudkan keseimbangan ekonomi masyarakat. Hal ini dikarenakan prinsip kepemilikan menurut Islam, mengatur bahwa pengelolaan harta tidak hanya dikuasai secara pribadi atau kelompok anggota masyarakat tertentu saja, namun juga oleh kelompok ekonomi lemah agar tidak terjadi ketimpangan ekonomi yang terlalu tinggi dalam masyarakat. Dengan demikian wakaf merupakan salah satu solusi untuk mewujudkan keadilan ekonomi guna mewujudkan kesejahteraan umum yang merupakan salah satu tujuan nasional Indonesia sebagaimana disebutkan dalam pembukaan UUD NRI 1945.

Kata kunci: hukum islam, implementasi, wakaf

\section{A. Introduction}

One of the considerations of the establishment of the Law Number 41 of 2004 on Waqf (the Waqf Law) is economic benefits of wider waqf. Waqf is no longer only intended for religious purposes. It also aims to advance public welfare following the potential and economic benefits of waqf property. It allows the management of waqf property to enter economic activities in the broadest sense as long as the management is in accordance with principles of sharia management and economy.

A waqf that is intended for public purposes (waqf khairi) is one of the potentials of public finance in Islam. In addition, waqf is a form of community contribution to improve welfare and empower a weak economy class. The Waqf Law aims to alleviate progress and national economic unity. This is in line with the Article 33 of the 1945 Constitution that the national economy is based on economic democracy with the principles of togetherness, equitable efficiency, sustainability, environmental insight, independence, and by maintaining a balance of progress and national economic unity. Furthermore, the objectives of the Waqf Law are also in line with the objectives of the Indonesian state in the $4^{\text {th }}$ paragraph of the Preamble of the 1945 Constitution, namely the realization of public welfare. Public welfare in the economic sector is one of the most important sectors in national development. Therefore, the Waqf Law is part of the presence of the state in this case the government to create public welfare through the Islamic economic sector.

Historically, Islam has several ideas of economic justice that can be classified into two approaches: qawliyya and qawniyya. ${ }^{1}$ First, the qawliyya approach is an approach that elaborates normative-prescriptive economic ideas, both originating from the Quran and Sunnah. ${ }^{2}$ Second, the qawniyya approach is carried out

\footnotetext{
1 Zakiyuddin Baidhawy, Rekonstruksi Keadilan Etika Sosial-Ekonomi Islam untuk Kesejahteraan Universal, Salatiga: Stain Salatiga Press, 2007, p. 33.

$2 \quad$ Ibid.
} 
through the exploration of Islamic economic ideas from an empirical perspective. It observes the symptoms of social activity directly, hence born a variety of positive empirical thoughts in this field. ${ }^{3}$

Justice is the most important principle in the mechanism of the Islamic economy. Umer Chapra, an Islamic economist from India, argues that based on the aspect of Islamic creed, the Quran places justice as virtue and piety. ${ }^{4}$ One of the important and fundamental concepts that are the subject of Islamic economic philosophy is the concepts of maqasid at-tasyri or maqasid al-shari'ah that emphasizes that welfare in Islamic economics is prescribed to realize and maintain the benefit of humanity. Scholars have recognized this concept, through the sharia maqasid they formulate the rules (legal theory that where there is benefit, there is the law of God. ${ }^{5}$ The aim of the prescribed Islamic law is for the benefit of humankind. ${ }^{6}$

To better understand the concept of justice in Islam, this article explains the meaning of justice, the implementation of economic activities through waqf instruments, and the role of waqf in efforts to realize social welfare according to the provisions of the laws in force in Indonesia. The identification is interesting because generally, the Indonesian people interpret waqf in a limited manner as ritual. For example, before the enactment of the Waqf Law, a land is an object oriented towards ritual worship purposes only.

There have been some scientific articles about productive waqf based on the Waqf Law, Implementation of Corporate Social Responsibility through waqf, and Implementation of justice distribution through Waqf in efforts to alleviate poverty, the responsibility of nazhir shares waqf, Waqf Intellectual Property Rights, and several other writings related to waqf. In an article on the implementation of waqf to create economic justice according to Islamic Law, there is a difference with previous article. The discussion of this article focuses on the concepts of justice according to Islam as well as the application of the concept of justice in question related to economic justice, which is realized through waqf instruments based on the laws and regulations in Indonesia.

It is expected that this article can provide understanding of the concept of economic justice according to Islam, and its implementation through waqf. In addition, it is also expected to deepen the understanding of the concept of justice according to Islam as a contribution of thought to the development of law,

\footnotetext{
Ibid., pp. 37-38.
}

$4 \quad$ M. Umer Chapra, "The Future of Economic : An Islamic Perspektive ", cited in Muslimin H. Kara, Bank Syari'ah di Indonesia, Analisis Kebijakan Pemerintah Indonesia Terhadap Perbankan Syari'ah, Yogyakarta: UII Press, 2005, p. 43.

5 Muhammad Sa'id Ramdan al-Buti, Dawabit al-Maslahah fi as-Syari'ah al-Islamiyah, Beirut: Mu'assasah arRisalah, 1977, p. 12.

$6 \quad$ Nur Ahmad dan M.Ridwan, “Kajian Maqasid Syari'ah dalam Penetapan Hukum”, Jurnal Pemikiran Hukum dan Hukum Islam, Edition XIV, 2011, p. 5. 
especially economic law, and the implementation of policies related to waqf. In particular, this article aims to contribute some insights how eradicate poverty in Indonesia through waqf to realize public welfare as one of the national goals stated in the Preamble of the 1945 Constitution of the Republic of Indonesia.

\section{B. The Scope of Justice on the Perspective of Islam}

\section{Meaning and Understanding of Justice}

The word justice comes from the Latin justicia, which means law or rights. Therefore, justice is always related to law. Justice is one of the most discussed objectives of law in the history of legal philosophy. In fact, some opinions state that law must be combined with justice, so it really means as a law. ${ }^{7}$ Justice, according to law, means and is comparable to fairness. Here, a person is said to act unfairly if the person takes more than the proper. People who disregard the law are also unjust, because everything that is based on the law can be considered as fair. ${ }^{8}$

For most people, justice is a general principle, that individuals should receive what they deserve. ${ }^{9}$ Some call it the term legal justice or legal justice that refers to the implementation of the law according to the principles set out in the rule of law. The term social justice is defined as general conceptions of social firmness or social justice that may or may not be in conflict with individual conceptions or justice in general. $^{10}$

\section{Justice Based on the Perspective of Islam}

The most commonly mentioned word in the Quran after 'Allah' and 'Science' is 'justice'. The word is mentioned more than one thousand times. It shows the value of justice in Islam is related to social, political, and social economic aspects. ${ }^{11}$ Justice in Islamic law covers various aspects of life, especially in the field and legal system. Justice includes justice in various relationships: between individual and self, among individuals, between humans and society, between individuals and judges, as well as relations with various related parties. ${ }^{12}$ It includes various economic activities and transactions. ${ }^{13}$

Justice is also one of the great qualities of Allah and one of the names in AlAsma 'ul-Husna (God's good names). Justice is the reason of the creation of the

\footnotetext{
H. M. Agus Santoso, Hukum, Moral, \& Keadilan, Jakarta: Kencana Prenada Media Group, 2014, p. 91.

Darji Darmodiharjo dan Shidarta, Pokok-Pokok Filsafat Hukum, Apa dan Bagaimana Filsafat Hukum Indonesia, Jakarta: PT. Gramedia Pustaka Utama, 1996. p. 14.

H. M. Agus Santoso, op.cit., p. 84.

Ibid.

11 Ahmad Muflih Saefuddin, cited in Wawasan Islam dan Ekonomi Sebuah Bunga Rampai, Jakarta: Lembaga Penerbit Fakultas Ekonomi Universitas Indonesia, 1997, p. 132.

12 Juhaya S. Praja, Filsafat Hukum Islam, Bandung: Pusat Penerbitan Universitas, 1995, p. 72.

13 Zakiyuddin Baidhawi, op.cit., p. 12.
} 
earth and the heavens and the assignment of God's messenger and the holy books. ${ }^{14}$ It is mentioned in the Quran (57: 25).

"Indeed, we have sent Our Apostles by bringing concrete evidence and we have sent down with them the Scriptures and balance (justice) so that humans can carry out justice ...".

"We have already sent Our messengers with clear evidences and sent down with them the Scripture and the balance that the people may maintain [their affairs] in justice. And We sent down iron, wherein is great military might and benefits for the people, and so that Allah may make evident those who support Him and His messengers unseen. Indeed, Allah is Powerful and Exalted in Might."

\section{a. Understanding Justice according to Islamic Law}

Justice is a simple translation of the word ' $a d l .{ }^{15}$ There are several other words which are considered to have the same meaning but different in certain emphases, such as qisț, qashad, mizan, wasath, qawwam, and hishsh. ${ }^{16}$ The following elaborates them. ${ }^{17}$

\section{1) Al-'AdI}

Etymologically, the term 'justice' in Arabic and Quran is referred by the word 'adl. It means mental strength or istiqamah, the opposite of deviation (al-jawr). ${ }^{18}$ Therefore, justice in sharia is interpreted as being consistent in the way of truth by avoiding anything that is forbidden by the religion. ${ }^{19}$ In the Quran, the word adl with its various forms is mentioned 28 times. ${ }^{20}$ Justice as a concept is referred by the words al-'adl or al'-idl. These two terms are close together in their understanding; the first is usually used with regard to everything that is understood through reason (al-basrirah), such as legal matters, while the second relates to something understood through sense or sensory power (al-hassah) such as the scale, quantity and size. ${ }^{21}$

Justice that is related to the field of law can be found in Chapter 4: 58 as follows.

\footnotetext{
14 Yusuf Qardawi, Hukum Zakat, Bandung: Mizan, 1999, p. 1039.

15 In the conception of Islam, the term justice is mentioned in Arabic word 'adl', which is a noun that is derrived from the verb adala. It means (1) straightening or honest, changing; (2) stay away, leaving from one (wrong) road to the right one; (3) to be the same or in accordance or equal; (4) making balanced or balancing or in a balanced state. See H. M. Agus Santoso, loc.cit.

16 Majid Khadduri, The Islamic Conception of Justice, Maryland: The Jhons Hopkins University Press, 1984, p. 6.

17 Zakiyuddin Baidhawi, op.cit., pp. 84-101.

$18 \quad$ Ibid., p. 84.

19 Hasbi Hasan, Pemikiran dan Perkembangan Hukum Ekonomi Syariah di Dunia Islam Kontemporer, Depok: Gramata Publishing, 2011, p. 81

20 Muhammad Fuad Abdul Baqi dalam Zakiyuddin Baidhawi, loc.cit.

21 Ibid.
} 


\begin{abstract}
"Verily, Allah tells you to deliver the message to those who have the right to receive it, and (to ask you) if you establish a law between humans so that you determine it fairly. Surely Allah gives you the best teaching. Surely Allah is All-Hearing, and All-Seeing.

"Indeed, Allah commands you to render trusts to whom they are due and when you judge between people to judge with justice. Excellent is that which Allah instructs you. Indeed, Allah is ever Hearing and Seeing." 22
\end{abstract}

In addition, the term 'al-'adl is used in speech. It means telling the truth or not lying. ${ }^{23}$ Likewise, 'al-adl implies ransom (al-fidyah) ${ }^{24}$ relating to the matter of the act of associating partners with Allah or shirk namely making comparisons and similarities with God with other creatures in terms of prayer and worship, with the intention of eliminating mudharat and taking advantage of what is seen equal to that God. ${ }^{25}$ Furthermore, al-adl in Quran also deals with justice relating to the structure of human anatomy that is created perfectly and proportionally. ${ }^{26}$

\title{
2) Al-Qist
}

Another word in the Quran which emphasizes justice is qist. ${ }^{27}$ The word is mentioned 25 times in various forms. The word means to divide fairly (al-nashib bi al'adl), also to mean al-mizan' al-hishshah, and al-nashib. Following wazan tafa'ala, the verb taqassatha means to share things fairly and equally (taqassama bi al-ladl wa sawa'). The opposite is al-jawr a deviation. ${ }^{28}$ The following two verses do not merely indicate that qist means justice, but it is also juxtaposed with the word ' $a d l$ itself.

"And if you fear that you will not deal justly with the orphan girls, then marry those that please you of [other] women, two or three or four. But if you fear that you will not be just, then [marry only] one or those your right hand possesses. That is more suitable that you may not incline [to injustice]." (4:3)

Then in Chapter 49: 9 as follows:

\footnotetext{
Al-Qurán dan Tafsirnya Jilid II, op.cit., p. 208.

See the Quran (Chapter Al-An'am [6]:152) "And if you say, then you should be fair even to relatives".

24 See the Quran (Chapter al-Baqarah [2]: 48) " And guard yourself from (the doom) of the day (doomsday, which on that day) one cannot defend another person, even if at all; and (likewise) they are not accepted by the Shafi'at and ransom from them, and they will not be helped".

25 See the Quran (Chapter Al-'An'am [6]: 1) "Praise be to Allah Who created the heavens and the earth and held darkness and light, but those who disbelieve associate (something) with their Lord."

26 See the Quran (Chapter al-Infithaar [82] : 7) "Which has made you then perfect your events and make your (body composition) proportional"

27 Syahrul Anwar, Ilmu Fiqh \& Ushul Fiqh, Bogor: Penerbit Ghalia Indonesia, 2010, p. 50.

28 Zakiyuddin Baidhawy, op.cit., pp. 88-89.
} 
"And if there are two groups of believers at war then make peace between the two. If one of the two groups is persecuting the other group, then fight the group that is doing the persecution so that the group returns to God's command; if the group has returned (to the command of Allah), then reconcile between the two fairly and fairly. Truly, Allah likes those who are just." ${ }^{\prime 29}$

The word that directly relates to the issue of economic justice is mentioned in Chapter al-Isra (17): 35 as follows; "and complete the measure if you measure, and weigh it with the correct balance. That is more important (for you) and better consequences. " 30

In this verse, Allah commands the Muslims to complete their measurements. When measuring the goods, it must be carried out accurately and accurately, not to reduce or exaggerate the measurements. In this verse, Allah orders them to weigh the goods with the correct balance. A true balance sheet is made as accurately as possible, so that it can give confidence to people who make buying, selling and does not allow the addition and subtraction. ${ }^{31}$

\section{3) Al-Mizan}

Two other words that are related to justice and very important to form a guarantee of justice in Islam are Mizan and Wasath. The first shows more on the importance of creating balance (tawazun) while the second contains a moderate understanding (tawassuth) in life. In Islamic teachings, tawazun can be seen starting from the issue of faith (belief), worship, morals, etc. ${ }^{32}$

The word mizan' is derived from wzn, meaning to weigh something else that is balanced. Mizan' is importance to measure the activities of human deeds fairly. Jubair, narrated from al-Dahhak, that mizan' is justice. It also means equality. The term mizan' is mentioned in the Quran 23 times. Most of the verses are related to economic activities in the form of weighing or measuring, as mentioned in Chapter al-Araf (7): 85 as follows.

"And (We have sent) to the inhabitants of Madyan their brother Shu'aib. He said: "O my people, worship God, there is no god for you but Him. Indeed, evidence has come to you from your Lord. Do not

\footnotetext{
29 Al-Qurán dan Tafsirnya Jilid IX, op.cit., p. 426.

30 Al-Qurán dan Tafsirnya Jilid V, The original manuscript belongs to the Ministry of Religion of the Republic of Indonesia with Reprint Permission Letter of the Minister of Religion of the Republic of Indonesia number D/B.A.00/5066/1990 on December 20, 1990, Yogyakarta: Universitas Islam Indonesia, Reprint Implementer PT. Dana Bhakti Wakaf UII, 1995, p. 552.

31 lbid., p. 575.

32 Ali Fikri, "Karakteristik-Karakteristik Umum Ajaran Islam" cited in Wawasan Islam dan Ekonomi sebuah Bunga Rampai, Jakarta: Lembaga Penerbit Fakultas Ekonomi Universitas Indonesia, 1997, p. 15.
} 
make mischief on earth after God has repaired it. That is better for you if you are truly a believer. "33

The above verse tells us that the people of Madyan, or the people of Prophet Shu'aib (Jethro), do not give thanks to Allah. Aside from their associating partners with Him, their morals are also very degenerate. Their lives are full of fraud, to economic matters in terms of weighing. According to a history when foreigners came to visit, they agreed to accuse that money under foreigners was fake, so they exchanged it at a very low price. Then Allah sent Shu'aib to show them the right path to leave the tyranny especially in the form of a reduction in human rights which they did by means of treason in the scales. From this verse, we can conclude that one of the meanings of Mizan' in relation to justice is to avoid fraudulent acts or taking the rights of others in economic activities.

\section{4) Al-Wasath}

Wasath literally means something that is located between two ends. This word is mentioned five times in the Quran. It has two meaning. First, it means middle, as mentioned in al-Quran Chapter al-Baqarah (2): 238: "Keep all your prayers and keep your prayers (middle of prayer). Stand because of Allah (in your prayer) with solemnity". The second understanding of wasath is fair, as mentioned in Chapter al-Baqarah (2): 143 as follows.

"And likewise (also) We have made you (Muslims) a just and chosen people so that you are witnesses of man's (deeds) and that the Apostle (Muhammad) bears witness to man's (deeds) and that the Apostle (Muhammad) be witnesses of (deeds) you. And We do not set the Qibla that becomes your Qibla (now), but so that We know (so that) it is real who follows the Apostles and who defects. And indeed (the transfer of Qibla), it feels very heavy, except for those who have been instructed by Allah; and Allah will not waste your faith. Verily, Allah is Most Gracious, Most Merciful to humans."

\section{5) Al-Qashd}

The term justice is also referred by the word qashd, which means a straight path (istiqamah al-thariq). ${ }^{34}$ Likewise, qashd also directly implies justice. This word by various forms is mentioned in the Quran. First, iqtishad is in the sense of praise and simplicity (al-jud). It is an attitude between excessive and griping, fast and slow, and far and near. ${ }^{35}$ The other side of iqtishad is frugality, which is an attitude between excessive and deficient (bayn ifrath wa tafrith), and between courage (al-

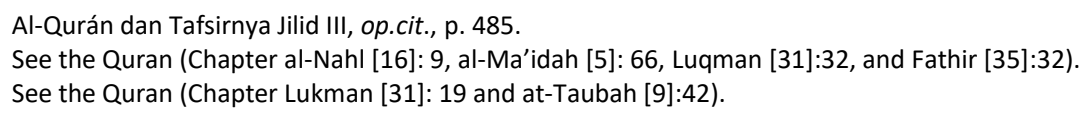


syaja'ah) that is between bravery and fear (bayn al-tahawwur wa al-jubn). Therefore, this word represents the middle attitude between two things. This term is also used to give the branch of economics, 'ilm al-iqtishad. ${ }^{36}$ Second, iqtishad is an attitude of doubt between fair and deviant. It is derived from the word qashd that also contains a negative meaning of force and disability. Therefore, there are similarities between the words adl, qist, and qashd, which are multi-interpreted expressions. $^{37}$

\section{6) Al-Qawwam}

Two other meanings that are close to justice in the Quran are qawwam and istiqamah or mustaqim, which are derived from the word qwm. It means upright, straight, and honest. ${ }^{38}$ In a few verses, these two words are used together with justice, for example in Chapter an-Nissā (4): 135.

"O believers! Be your upholder of justice, be a witness because of Allah, even against yourself or against your mother and father and your relatives. If he (the accused) is rich or poor, then Allah knows better the benefits (his goodness). Then do not follow the passions because you want to deviate from the truth. And if you distort (words) or are reluctant to be a witness, then know Allah is all-pervasive in everything you do".

\section{7) Al-Hishsh}

Another word that also means justice is hishsh. This word literally means cut, divide, and clear or bright. In Lisan al-'Arab, Ibn Manzur explains that al-hishshah means distributing food, drink, land, etc. ${ }^{39}$ From the word 'distribution', it is implied that the distribution of wealth or goods and services must be done clearly (honestly) and transparently to both individuals and groups or social classes. This word is mentioned once in the Quran in Chapter Yusuf (21): 51.

"The king said (to the women):" How were you when you tempted Joseph to subject him (to you)? They say, 'Allah is perfect, we do not know anything bad thereof'. Al-Aziz's wife says, 'Now the truth is clear, I am the one who tempted him to submit himself (to me), and in fact he is among those who are righteous.'."40

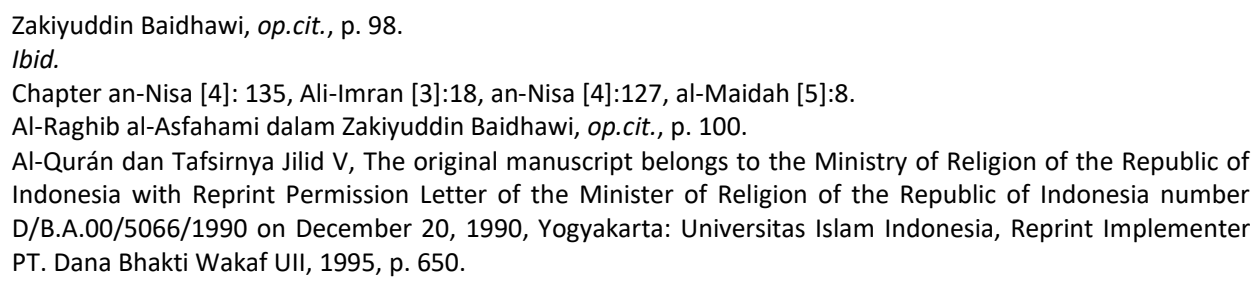
Indonesia with Reprint Permission Letter of the Minister of Religion of the Republic of Indonesia number D/B.A.00/5066/1990 on December 20, 1990, Yogyakarta: Universitas Islam Indonesia, Reprint Implementer PT. Dana Bhakti Wakaf UII, 1995, p. 650. 
All of the meanings of justice underline the importance of upholding the justice system in various fields of human life including economics and efforts to obtain theological confirmation from the Quran by emphasizing the terms about justice, namely al-'adl, al-qitsh, al-qashdh, al-qawwam, al-hishsh, al-mizan', and alwasath. $^{41}$

Justice in the word adl has the meaning of straightening or being honest, changing, moving away, leaving from wrong path to the right path, becoming equal or conforming or equalizing, making balanced or balancing or in a balanced state. In the Quran, the concept of justice has similarities with qist (equality), mizan (balance), and haqq (truth). Based on the various meanings, justice is to create a balanced state by upholding the values of truth and avoiding forms of tyranny or error. This condition is basically one of the basic human needs both personally, and in a personal relationship with the community. In terms of justice in the economy, it is a condition that does not favour one party or certain group in the economy, so creating justice is an unavoidable obligation in the Islamic economy. ${ }^{42}$

Likewise, the definition of justice in the word al-hishsh has to do with justice in economic distribution. Al-Hishsh contains the meaning of cutting, dividing, and clear or clear. As its implementation in waqf, it is an effort to achieve economic justice through the distribution of the benefits of waqf objects, which are carried out honestly and transparently. Therefore, the goal of economic distribution through waqf can be achieved.

\section{b. Justice in the Economy according to Islamic Law}

Economic justice according to Islamic teachings is a distributive justice, based on the Quran, Chapter al-Hasyr (59): 7. The Quran emphasizes that a group of people are not allowed to be too rich while other groups are increasingly impoverished. ${ }^{43}$ This condition is contrary to the nature of humanity based on monotheism. The teachings of monotheism have implications for the guarantee of equality and unity among fellow human beings in processing and reaping the results of natural resources and utilizing them for the lives of fellow humans fairly. This distributive justice is rooted in the Islamic concept of human security to Allah and fellow humans (see Chapter Ali-Imran [3]: 180 and Al-Hadid [57]: 7) and the environment. ${ }^{44}$

Distribution justice is justice that shares the general welfare of each citizen in accordance with his or her respective services and needs. In distribution justice, the distribution of wealth and income is based on universally accepted norms of

\footnotetext{
Zakiyuddin Baidhawi, op.cit., p. 101.

42 Ruslan Abdul Ghofur Noor, Konsep Distribusi dalam Ekonomi Islam dan Format Keadilan Ekonomi di Indonesia, Yogyakarta: Pustaka Pelajar, 2013, p. 83.

43 Zaki Fuad Chalil, Pemerataan Distribusi Kekayaan dalam Ekonomi Islam, Jakarta: Erlangga, 2009, p. 392.

44 Ibid.
} 
justice. Islamic teachings require that every individual and society must respect other human rights. Therefore, everyone has the same and fair opportunity to improve their standard of living. Community order will be formed more justly. Islam obliges rich groups to help and help those who are economically weak. Therefore, in this way, every citizen can achieve basic welfare or at least the minimum level as a human being. In this case, the government of a state is responsible to realize the minimum needs of all citizens. ${ }^{45}$

Efforts to achieve individual and social welfare in Islam, it appears that in the management of wealth in Islam, there is recognition of individual ownership. On the other hand, there are social obligations for the wealthy people, such as the obligation of zakat (a kind of charity) after Nisab (specific numbers), or shadaqa (alms) and waqf. Through the mechanisms, balance can be realized in society because of basic principle of ownership in Islam that assets should not only be located and revolve in the hands of certain individuals (groups of) members of the community. Distributive justice in the economy according to Islam is so that wealth does not accumulate in a small part of people, but always circulates. The justice guarantees the creation of a fair share of prosperity, so that it will contribute to a better quality of life. ${ }^{46}$

Distribution of income in Islam is done through commercial economic activities that follow the market mechanism, as well as through a distribution system that relies on aspects of social justice. The first distribution system takes place through an economic process. Among salaries or wages for workers, the cost of renting land, as well as other means of production, the profits of those who run businesses through the mudarabah mechanism whose business capital is obtained through the musyarakah mechanism. Zakat, infaq, and shadaqa are forms of income distribution system. Islam requires and encourages the realization of a balance of income, because not everyone is able to engage in economic processes properly. ${ }^{47}$

Economic balance is the goal of the implementation of Islamic economic system, as a basis for efforts to balance the economy as reflected in the mechanisms established in Islam, so that no decomposition occurs in certain sectors of the economy in the absence of optimization to move all the potential and elements that exist in macro scale. ${ }^{48}$

Ibn Khaldun, a Muslim sociologist and economist, argues that the principle of justice has not been applied since there are oppressions and exploitations among fellow human beings. The development of a society can be hampered. If this

\footnotetext{
$45 \quad$ lbid., p. 383.

46 Syed Nawab Haidar Naqi cited in Ruslan Abdul Ghofur Noor, Konsep Distribusi dalam Ekonomi Islam, Yogyakarta: Pustaka Pelajar, 2013, p. 84.

$47 \quad$ Zaki Fuad Chalil, op.cit., p. 394.

48 Sukamdani Sahid Gitosardjono, Bisnis dan Kewirausahaan Syari'ah upaya menuju Kesejahteraan Umat Islam, Bogor: Sekolah Tinggi Agama Islam Terpadu (STAIT) Modern Sahid, 2012, p. 20.
} 
happens, it will result in the decline and destruction of the country. Thus, justice is a principle that must be upheld in national development. ${ }^{49}$

In the Islamic concept, the fulfillment of social interests is the responsibility of the government. The government is responsible for providing, maintaining, and operating public utilities to ensure the fulfillment of social interests. ${ }^{50}$ This is found during the early days of Islam. During the time of Prophet Muhammad, the availability of clean water for every household was the country's main concern. In the years that followed, at the beginning of the Hijri century, in line with the increasingly vast territory of the Islamic caliphate, the state did a lot of construction and maintenance of roads, bridges, and irrigation canals, which at that time were the main needs of the community. ${ }^{51}$ Systematically, the balancing tools for the economy in Islam are in the following forms. ${ }^{52}$

i. Obligation of zakat on assets that are not invested. It encourages owner of property to invest the property. At the same time, zakat is not required except for the duration of the assets invested. In this case, Islam does not recognize the minimum limit for profit, thus causing the owner of the property to invest his property even though the possibility of loss up to the mandatory zakat restrictions issued. Thus, the possibility of recession in Islam can be avoided.

ii. The profit sharing system in business replaces the interest system has opened up equal opportunities between investors and entrepreneurs. The interest system can be eliminated in the profit sharing system. In addition, this system can also balance the monetary sector and the real sector.

iii. There is a close relationship between the monetary authority and the state expenditure sector. Money printing is not possible, unless there are causes of the real economy. This can reduce inflation.

iv. Fairness in the distribution of income and assets where the poor improve their consumption patterns with the zakat mechanism. Therefore, purchasing power of the lower class increases with the real demand in the community and the availability of jobs.

v. State has a right of intervention in the economy. The state has the authority to intervene in the wheel of the economy on certain things that cannot be left to the private sector to run them, for example in building public facilities and meeting basic needs for the community.

Ibid.

50 Nurul Huda, Achmad Aliyadin (et. al), Keuangan Publik Pendekatan Teoritis dan Sejarah, Jakarta: Kencana 2012, p. 1.

51 Ibid.

52 Gitosardjono, Sukamdani Sahid Gitosardjono, Bisnis dan Kewirausahaan Syariah Upaya menuju Kesejahteraan Umat Islam, Bogor: Sekolah Tinggi Agama Islam Terpadu (STAIT) Modern Sahid, 2012, pp. 2021. 
The realization of public interest is a collective responsibility between government and society. Islam requires a society to arrange that can ensure the fulfilment of needs in society. The people themselves can fulfil some of them, while state can fulfil others. ${ }^{53}$

Considering the important role of the state in Islam, including its role in managing the economic and public sectors, the function of the state in managing the economic and public sectors is divided into three functions as follows.

i. The allocation function. The allocation function can be carried out by three main elements in the economy: market, state, and state organizations. ${ }^{54}$ The three interact with one another in an economic country and encourage transfers between elements to create justice and economic balance. In order to allocate state resources among community members, the three elements integrate actions so that all three have a comprehensive agenda for managing the country. If the three elements coordinate with each other in their actions and policies, then overlapping policies can be minimized. Thus, the resources of state become more optimal in their utilizations. ${ }^{55}$

ii. Distribution Function. The distribution function means that state must be able to guarantee that every member of society can enjoy a fair welfare. If state allocation function regulates the allocation of economic resources to be used fairly and efficiently, then the distribution function, the state must ensure that all members of society can enjoy the results of development in the form of meeting the minimum living needs. ${ }^{56}$ Islam calls for the equitable distribution of national wealth of the country. It is an obligation of a country to implement this policy. ${ }^{57}$

iii. Stabilization function. The stabilization function is a socioeconomic condition that has minimal risk so that humans have certainty of expectations towards the growth and utility of economic resources as well as harmony of dynamic social interactions both now and for the future. ${ }^{58}$ The target of national stability is the creation of dynamic and harmonious social interactions, so that each individual can enjoy a strong social life spiritually, prosperously, and fairly.

\section{Waqf in the Context of realizing Economic Justice According to Islam}

In the economy, justice must be applied in all fields, in the process of either production, distribution, or consumption. Justice here also means the policy of

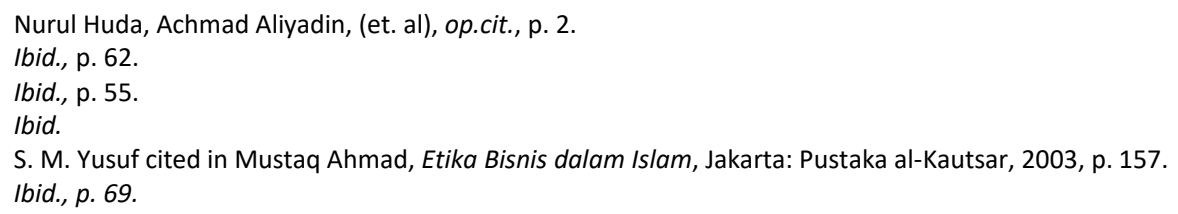


allocating a certain amount of economic activity results for people unable to enter the market, through zakat, infaq, shadaqa, or waqf, especially to the poor people every opportunity that is not determined, both the type, amount, and time. ${ }^{59}$

In Islamic teachings, there is an obligation for fellow members of community to take care and be responsible for other members, especially those belonging to the economically weak group. This is related to the existence of the obligation of zakat for wealthy people, including giving waqf.

Waqf in Islam has been known along with the era of Prophet Muhammad, marked by the construction of the Quba Mosque. Then followed by the construction of the Nabawi Mosque, which was built on orphaned land from the Bani Najjar. The land was bought by the Messenger of Allah. The Messenger of Allah endowed the land he had bought for the mosque to be built, and then his companions provided support in the form of waqf for the completion of the mosque construction. ${ }^{60}$

Waqf is usually carried out as utilization of individual assets. However, it has undergone various changes, both at the level of the paradigm and in the practice of its implementation. At the paradigm level, waqf has evolved from merely the use of an immovable object in the form of land and buildings, now endeavoured by the use of the object in order to have a productive economic charge. At the level of practice, waqf is now beginning to be developed in the form of utilizing the means of production and economic tools such as money, stocks, etc. ${ }^{61}$

Waqf institution as one of the pillars of Islamic economics is very closely related to the socio-economic problems of the community. ${ }^{62}$ The realization of waqf to realize economic distribution justice is one of the efforts to realize social justice in the economic field. The meaning of social justice itself is associated with Hatta's view of the precepts of social justice for all Indonesian people more directing the meaning of justice in the economic sense. Hatta says that social justice is a decisive step to implement a just and civilized Indonesia. The Founding Fathers of Indonesia who compiled the 1945 Constitution had the conviction that the ideals of social justice in the economic field could achieve equitable prosperity. Furthermore, detailed implementation steps to achieve a fair and prosperous state (including the minimum wage provisions, provision of housing, health care, and procurement of reserves by employers for workers, levelling community income, developing cooperatives) are in accordance with the demands of modern times. It must implement guided economy in accordance with the government's plan to achieve

\footnotetext{
59 Mohammad Daud Ali, Sistem Ekonomi Islam, Zakat dan Wakaf, Jakarta: Universitas Indonesia UI Press, Jakarta, 1988, p. 8.

60 Mundzir Qahaf cited in Suhrawardi K.Lubis, Wakaf \& Pemberdayaan Umat, Jakarta: Sinar Grafika, 2010, p. 99.

61 Kementerian Agama Negara RI, Model Pengembangan Wakaf Produktif, Jakarta: Direktorat Jenderal Bimbingan Masyarakat Islam, Direktorat Pemberdayaan Wakaf, 2010, p. 3.

62 Kementerian Departeman Agama RI, Kementerian Agama Republik Indonesia, Paradigma Baru Wakaf di Indonesia, Jakarta: Direktorat Jenderal Bimbingan Masyarakat Islam, 2008, p. 10.
} 
maximum prosperity for the people, the implementation of education, maintenance of the poor and neglected children, and the provision of Social Security to the Community. ${ }^{63}$

Waqf as one of the distribution patterns in Islamic teachings in an effort to create social justice is also an implementation of the realization of justice according to the meaning of al-hishshah, which means to cut, to divide, and to clear. Based on these terms, waqf is to make the distribution of benefits to run honestly and transparently. There should not be deviation from the purpose of waqf in accordance with its vision.

Waqf as a form of implementation to distribute the economy, the principle of the Quran explains explicitly about the goals and strategies of distribution as follows. ${ }^{64}$

a. Distribution and redistribution intend to meet the needs of all creatures. This is the main purpose of the transfer of wealth determined by the Quran.

b. In terms of motive, both distribution and redistribution must be intended to result a positive impact, this is a goal that cannot yet be offered by the principles of contemporary justice and other economic systems but obtains reinforcement from the texts of the Quran and Shari'a. Some examples of positive effects on personality are cleaning or purifying the soul and wealth (tuthahhiruhum wa tuzakkihim biha) the giver will strengthen the giver's faith $^{65}$, instil the habit of helping others ${ }^{66}$, and encourage others to give infaq. This is a wisdom that calls openly for humans to give. As confirmed in the Quran that whatever is donated from good property, then he will get the best return from him. It also creates good will among the people. According to the Quran, it is important to give alms without being accompanied by things that bring hatred, even though the alms provide economic benefits for the recipient. Allah says that good words (qawl ma'ruf) and forgiveness (maghirah) are better than charity or alms followed by things that hurt the recipient's heart (manna wa adha). ${ }^{67}$

c. Distribution and redistribution must reduce disparities in the distribution of wealth and income. Economists usually talk about Guaranteed Minimum Living Needs and reduction of disparity as two different things. The Quran distinguishes between the two and emphasizes the importance of the first.

d. Distribution and redistribution aim to make better use of natural resources and fixed assets. There is a positive relationship between redistribution and

Mohammad Hatta cited in The Liang Gie, Teori-Teori Keadilan, Yogyakarta: Penerbit Surya, 1979, pp. 5-6.

Zakiyuddin Baidhawy, op.cit., pp. 210-212.

See Chapter Al-Taubah (9): 103.

See Chapter Al-Baqarah 2: 265.

See Chapter Al-Baqarah 2: 263-264 
efficiency in terms of the impact of redistribution. This shows the truth about the discussion of giving surpluses to those in need.

Efforts to increase the role of waqf in order to provide maximum results in the welfare of society, in the provisions of the Waqf Law is regulated so that waqf assets are managed productively which can increase the results economically. Article 5 of the Waqf Law states that endowments function to realize the potential and economic benefits of endowments for the benefit of worship and for the benefit of the general welfare. This provision shows that waqf assets are managed productively so that they can provide an economic increase in an effort to improve the welfare of the community. Thus, waqf assets are expected not only to provide services for worship activities, but also to improve economic welfare.

Considering the important role of the state in Islam, including in its role in managing the economic and public sectors so that there is an equitable distribution that can be enjoyed by all levels of society, the state can intervene justice in the distribution of income and assets. This can be done by supporting policies and protection of waqf objects so that they can be used optimally and preventing and taking action against any misuse or misuse of the ownership or use of waqf objects.

\section{Conclusion}

The meaning of Justice as one of the principles in Islamic economics is related to the concept of maqasid al-shari'ah. It is the effort to create prosperity and benefit for the people. The values of social justice in Islam that are based on the Quran, including economic justice, encourage the achievement of a balanced welfare, both individually and socially. As a manifestation of one of the meanings of justice in the Islamic view, which comes from the word "adl", it means making a balance or balancing or in a balanced state. The word has similarities with qist (equality), mizan (balance), and haqq (truth). From some of these understandings related to economic justice in the Quran, it can be implemented through waqf. Waqf is an effort to realize economic justice according to Islam.

Waqf enables economic distribution. The utilization of distributed assets can be managed and empowered economically to be more productive to meet the economic needs of lower social class. There should not be high economic disparities in society. Waqf as an instrument of economic empowerment is one of the goals of waqf mentioned in the Article 22 of the Waqf Law. Thus, waqf can be one of the efforts to improve the welfare of the community, especially in efforts to reduce poverty. There is a need for synergy of all parties involved, both from the government, to create improvements in the regulation of waqf and supervision of waqf objects, as well as community participation for representation. 


\section{References}

\section{Books}

Al-Qurán dan Tafsirnya Jilid V, IV, IX, The original manuscript belongs to the Ministry of Religion of the Republic of Indonesia with Reprint Permission Letter of the Minister of Religion of the Republic of Indonesia number D/B.A.00/5066/1990 on December 20, 1990, Reprint Implementer PT. Dana Bhakti Wakaf UII, Yogyakarta, 1995.

Ahmad Muflih Saefuddin, cited in Wawasan Islam dan Ekonomi Sebuah Bunga Rampai, Editor Mustafa Kamal, Perbandingan Sistem Ekonomi Islam dengan Kapitalisme dan Marxisme, Lembaga Penerbit Fakultas Ekonomi Universitas Indonesia, Jakarta, 1997.

Ali Fikri, Karakteristik-Karakteristik Umum Ajaran Islam cited in Wawasan Islam dan Ekonomi sebuah Bunga Rampai, Editor Mustafa Kamal, Lembaga Penerbit Fakultas Ekonomi Universitas Indonesia, Jakarta, 1997.

Darji Darmodiharjo dan Shidarta, Pokok-Pokok Filsafat Hukum, Apa dan Bagaimana Filsafat Hukum Indonesia, Revised Edition, PT. Gramedia Pustaka Utama, Jakarta,1996.

Hasbi Hasan, Pemikiran dan Perkembangan Hukum Ekonomi Syariah di Dunia Islam Kontemporer,Gramata Publishing, Depok, 2011.

Juhaya S.Praja, Filsafat Hukum Islam, Pusat Penerbitan Universitas, Bandung, 1995. Kementerian Agama Negara RI, Model Pengembangan Wakaf Produktif, Direktorat Jenderal Bimbingan Masyarakat Islam, Direktorat Pemberdayaan Wakaf, Jakarta, 2010.

Kementerian Agama Republik Indonesia, Paradigma Baru Wakaf di Indonesia. Direktorat Jenderal Bimbingan Masyarakat Islam, Jakarta, 2008.

M. Agus Santoso, Hukum, Moral, \& Keadilan, Kencana Prenada Media Group, Jakarta, 2014.

M. Umer Chapra," The Future of Economic : An Islamic Perspektive ", in Muslimin H. Kara, Bank Syari'ah di Indonesia, Analisis Kebijakan Pemerintah Indonesia Terhadap Perbankan Syari'ah, UII Press, Yogyakarta, 2005.

Majid Khadduri, The Islamic Conception of justice, The Jhons Hopkins University Press, Maryland, 1984.

Mohammad Daud Ali, Sistem Ekonomi Islam, Zakat dan Wakaf, Universitas Indonesia, UI Press, Jakarta, 1988.

Muhammad Sa'id Ramdan al-Buti, Dawabit al-Maslahah fi as-Syari'ah al-Islamiyah, Mu'assasah ar-Risalah, Beirut, 1977.

Mustaq Ahmad, Etika Bisnis dalam Islam, Judul asli Business Ethics in Islam translated by Samson Rahman, Pustaka al-Kautsar, Jakarta, 2003.

Nurul Huda, Achmad Aliyadin (et.al), Keuangan Publik Pendekatan Teoritis dan Sejarah, Kencana, Jakarta, 2012. 
Ruslan Abdul Ghofur Noor, Konsep Distribusi dalam Ekonomi Islam dan Format Keadilan Ekonomi di Indonesia, Pustaka Pelajar, Yogyakarta, 2013.

Suhrawardi K.Lubis, Wakaf \& Pemberdayaan Umat, Sinar Grafika, Jakarta, 2010.

Sukamdani Sahid Gitosardjono, Bisnis dan Kewirausahaan Syari'ah upaya menuju Kesejahteraan Umat Islam, Sekolah Tinggi Agama Islam Terpadu (STAIT) Modern Sahid, Bogor, 2012.

Syahrul Anwar, Ilmu Fiqh \& Ushul Fiqh, Penerbit Ghalia Indonesia, Bogor, 2010.

The Liang Gie, Teori-Teori Keadilan, Penerbit Surya, Yogyakarta, 1979.

Yusuf Qardawi, Hukum Zakat, Mizan, Bandung, 1999.

Zakiyuddin Baidhawi, Rekonstruksi Keadilan Etika Sosial-Ekonomi Islam untuk Kesejahteraan Universal, Stain Salatiga Press, Salatiga, 2007.

Zaki Fuad Chalil, Pemerataan Distribusi Kekayaan dalam Ekonomi Islam, Erlangga, Jakarta, 2009.

\section{Other Documents}

Nur Ahmad dan M.Ridwan, "Kajian Maqasid Syari'ah dalam Penetapan Hukum", dalam Jurnal Pemikiran Hukum dan Hukum Islam, Program Studi Ahwal Syakhshiyyah- Jurusan Syari'ah Sekolah Tinggi Agama Islam Negeri Kudus, Edisi XIV, January-June 2011.

\section{Legal Documents}

The 1945 Constitution of the Republic of Indonesia [Undang-Undang Dasar Negara Republik Indonesia Tahun 1945].

Law Number 41 of 2004 on Waqf [Undang Undang Nomor 41 Tahun 2004 Tentang Wakaf]. 